\title{
Compliance with COVID-19 Mitigation Measures in the United States
}

Benjamin van Rooij* $\pm<$, Anne Leonore de Bruijn*, Chris Reinders Folmer*, Emmeke Kooistra*§, Malouke Esra Kuiper*§, Megan Brownlee*§, Elke Olthuis*§, \& Adam Fine ${ }^{\wedge 1}$

\footnotetext{
*University of Amsterdam, School of Law

\pm University of California, Irvine, School of Law

${ }^{\wedge}$ Arizona State University, School of Criminology and Criminal Justice $\S$ indicates that authors have had a comparable contribution to the paper <corresponding author: bvanrooij@,1aw.uci.edu or b.vanrooij@,uva.nl
}

\section{Abstract}

The COVID-19 mitigation measures require a fundamental shift in human behavior. The present study assesses what factors influence Americans to comply with the stay at home and social distancing measures. It analyzes data from an online survey, conducted on April 3 , 2020, of 570 participants from 35 states that have adopted such measures. The results show that while perceptual deterrence was not associated with compliance, people actually comply less when they fear the authorities. Further, two broad processes promote compliance. First, compliance depended on people's capacity to obey the rules, opportunity to break the rules, and self-control. As such, compliance results from their own personal abilities and the context in which they live. Second, compliance depended on people's intrinsic motivations, including substantive moral support and social norms. This paper discusses the implications of these findings for ensuring compliance to effectively mitigate the virus.

\section{Introduction}

In response to the COVID-19 pandemic, authorities across the globe have taken measures to slow the spread of the virus and protect vulnerable groups from contagion. These measures are vital in decreasing mortality and reducing the overburdening of health care systems. According to one estimate, mitigation measures can save at least 20 million lives and, when they are adopted early enough (at 0.2 deaths per 100,000 population per week), up to 38.7 million lives globally (Walker et al. 2020). As Dr. Deborah Birx, who is coordinating the coronavirus response in the US summarized on April 1, “There's no magic bullet. There's no magic vaccine or therapy. It's just behaviors. Each of our behaviors, translating into something that changes the course of this viral pandemic over the next 30 days." ${ }^{\prime 2}$ However, effectuating these measures, and ensuring people maintain social distance and refrain from 
unnecessary outdoor activities, in rich and poor areas, in authoritarian and in open societies, and do so for weeks and months at end is the ultimate human challenge. As written in an editorial in Science after the 1918 Pandemic that killed millions worldwide, "It does not lie in human nature for a man who thinks he has only a slight cold to shut himself up in rigid isolation as a means of protecting others on the bare chance that his cold may turn out to be a really dangerous infection" (Soper 1919).

This study answers two crucial questions in relation to these mitigation measures. First, it studies to what extent people have already complied with the measures. Second, it analyzes which of the possible mechanisms grounded in social science have actually shaped compliance. The answers to these questions can shed light on the extent to which the measures have been effective in achieving the desired change in behaviour, which can mitigate the spread of the virus. Moreover, they can help guide policies that seek to improve compliance.

The study focuses on two core contagion mitigation measures in the United States. One of these measures focuses on social distancing, which looks at whether people keep a safe distance from others (in most countries this has been defined at somewhere between 1,5-2 meters) and whether they refrain from meeting people outside of their own household. The other measure focuses on staying at home (which has been issued under different names, including stay at home orders, lockdowns, and shelter in place). While there is variation in the exact details of such measures, their core substance is that people are to stay at home and only go out for what are deemed essential activities (which have been defined differently in different jurisdictions). 


\section{Literature overview}

The study contributes to the emerging body of empirical work on the factors that influence how people respond to the COVID-19 mitigation measures. However, many studies do not focus on compliance with the measures themselves, but on the psychological impact of the measures, or other related psychological dimensions. Some of the earlier work, which came out when countries were still considering whether to take these measures, has assessed whether people support the measures, how they perceive the efficacy of the measures, and what explains such support (Kushner Gadarian, Wallace Goodman, and Pepinsky 2020, Maekelae et al. 2020). In addition, Zettler et al. (2020) examined what factors affect acceptance of personal restrictions due to COVID-19 measures, but did not measure actual behavior and compliance with these measures. Moreover, experimental studies have examined how different messages on the importance of COVID-19 mitigation measures affect self-reported intentional behavior to comply with these measures (Lunn et al. 2020, Everett et al. 2020).

There are some studies that have similarly asked people to self-report about their behaviour since measures have been adopted. These studies have not looked at what explains variation in such compliance. A recent Dutch survey, for instance, reported descriptive statistics on how self-reported behaviour has changed over time, and showed promising rates of compliance with social distancing measures. However, this study did not examine what factors influenced behavioral change (I\&O Research and Universiteit Twente 2020). Another example is a study, reported in the New York Times, that used de-identified cell-phone data to capture reductions in the average distance travelled after measures were adopted, compared to before the measures were adopted, in a specific area.(Glanz et al. 2020, April 2). This work 
showed that in the US, there is a marked reduction in movement in places where measures were adopted, compared to places that did not adopt measures. This sort of study provides reliable data on how much people move, but it does not provide data about compliance with the measures themselves, nor does it assess what shapes compliance.

Several recent studies did look at which factors influence compliance. These studies focused on particular influences, for example on the effects of political orientation (Harper et al. 2020, Kushner Gadarian, Wallace Goodman, and Pepinsky 2020), social responsibility, social trust, self-interest (Oosterhoff and Palmer 2020), and attitudes about COVID-19 severity or fear of the virus (Oosterhoff and Palmer 2020, Harper et al. 2020).

In sum, there is emerging empirical research about people's attitudes and responses to the measures. However, there are no studies yet that look at whether people comply with or violate the measures, and that systematically assess what factors shape such compliance. Here, it is vital that the analysis of compliance with COVID-19 mitigation measures uses a comprehensive compliance approach that draws on the behavioral mechanisms and interventions that are known to affect rule-compliant behavior based on insights from prior compliance research (Van Rooij and Sokol 2021 (Forthcoming)).

\section{Present study}

This study analyzes how people have responded to the measures adopted to mitigate the spread of COVID-19 in the US. As of April 1, 2020, approximately 70 percent of all Americans were subject to a stay at home measure. ${ }^{3}$ Although the terms "safer at home" and "shelter in place" were used interchangeably within the United States, ${ }^{4}$ measures generally allowed people to leave their home for essential activities, such as grocery shopping or doctor 
visits. ${ }^{5}$ Although a federal stay at home directive was never issued, many governors instituted statewide measures advising people to stay at home. ${ }^{6}$ Where a state order was not issued, many officials at the county and city level instituted similar measures. ${ }^{7}$ Social distancing measures, which advised citizens to maintain a six-foot space between themselves and other people ${ }^{8}$ and generally included the closure of schools and non-essential businesses, ${ }^{9}$ accompanied stay at home/shelter in place orders in most jurisdictions. The majority of social distancing recommendations were issued in March, with President Trump officially recommending social distancing guidelines on March 10, 2020. ${ }^{10}$

States have used different approaches to ensure compliance with these measures. Many states, including, Washington, California, and New York, have adopted sanctions (i.e., the imposition of fines and/or jail sentences) for offenders, seeking to deter people into compliance. To enforce these sanctions, some localities, such as Los Angeles, have increased law enforcement patrol. ${ }^{11}$ States have also focused on enhancing people's awareness of the measures. In Washington State, for instance, reminding alleged violators of what the measures are is a first priority before issuing citations or actual criminal action. ${ }^{12}$ In many localities, authorities have made it harder for people to gather in public, closing down public venues, and in New York City even taking away basketball hoops to keep people from gathering to play. ${ }^{13}$ Authorities also made moral appeals. For instance, in California, Governor Gavin Newsom discussed that 25 million people would be affected, and he appealed to people's sense of duty: “There's a social contract here, people I think recognize the need to do more to meet this situation."14 Leaders also argued that the measures could help "flatten the curve" (of infections) and prevent hospitals being unable to provide the care needed. ${ }^{15}$ 
To study compliance with the mitigating measures in the US, this study asked respondents to report the frequency in which they have engaged in the desired (or prohibited) behaviors. Earlier studies about compliance with health related measures have shown that there is concordance between self-report and objective compliance measures when such measures are used in diaries and surveys (as they are here), but not when used in interviews (Garber et al. 2004, Bachmann et al. 1999, Dieltjens et al. 2013, Rauscher et al. 1993, Ridgers et al. 2012).

To assess what explains variation in compliance, the study assessed a set of independent variables that potentially shape the way people have been responding to the measures. These have been operationalized on the basis of insights about compliance, and why people obey or break rules from a psychological, criminological, sociological, and economic perspective (Van Rooij and Sokol 2021 (Forthcoming), Friedman 2016, Feldman 2018).

The first type of factor we expected to influence compliance with the mitigation measures is substantive moral support for the measures. This refers to the extent to which people agree with the substance of the measures (Tyler 1997, 2006). As the virus seems to affect some people disproportionately (Zhou et al. 2020, Jung et al. 2020, Weiss and Murdoch 2020), for instance by having more serious and lethal effects for the elderly or for those with preexisting conditions and much less so for younger people, it is important to know how respondents see the threat to themselves and loved ones, as well as public health generally. We assessed whether people morally supported the measures themselves. Finally, we looked at whether people found the overall approach taken by authorities to be consistent and adequate. We used these insights to study whether more moral support for the measures was associated with higher compliance. 
The second factor with a potential influence on compliance is the costs of compliance and strain that people might incur following the measures. With higher costs of compliance, rational choice theory would predict that compliance will be lower (Paternoster and Simpson 1993, Donovan and Blake 1992). In addition, strain and negative emotions people may have because of the measures may push them to cope through rule violating behavior (Agnew 1992, 2006, Agnew et al. 2002, Agnew and White 1992, Baron 2004, Piquero and Sealock 2004, Botchkovar, Tittle, and Antonaccio 2009). Studies about emotions people may experience during quarantine also show that negative emotions may lead to lower compliance with quarantine measures (Brooks et al. 2020). We used these insights to study whether higher costs predicted less compliance, and also whether negative emotions predicted lower compliance.

The third type of factor with a potential influence on compliance is the deterrent effect of the measures. General deterrence theory holds that, when there is a greater certainty and severity of punishment, people become more likely to comply with rules (Becker 1968, Polinsky and Shavell 2000, Shavell 1991). Empirical studies have shown that certainty of punishment is especially important, and for criminal behavior, stronger punishment only starts to have an effect after there is a threshold level of such certainty (Nagin 2013, Brown 1978, Chamlin 1991). Perceptual deterrence research also shows that deterrence is subjective (Apel 2013, Decker, Wright, and Logie 1993) and that research needs to look at the perceptions people have of certainty, and the relative impact that punishment has on their lives (Grasmick and Bryjak 1980). These insights were used to assess whether higher certainty and higher severity of sanctions have a deterrent effect in improving compliance. 
The fourth type of factor with a potential influence on compliance is people's capacity to comply with the measures. Logically, compliance is lower when people are practically unable to do as the measures demand. Another aspect of the capacity to comply is whether people have sufficient knowledge to know what is expected from them (Darley, Carlsmith, and Robinson 2001, Kim 1999, Van Rooij 2021 (Forthcoming)). Moreover, the more unclear the rules are, the harder it is for people to know what is expected of them and thus the harder it is to comply (Feldman and Teichman 2009). We used these insights to study whether practical capacity to obey the rules had an effect on compliance, and whether the perceived clarity of the measures predicted compliance.

The fifth type of factor with a potential influence on compliance is whether people have the opportunity to violate the measures. Here, we follow insights from routine activities theory (Cohen and Felson 1979, Osgood et al. 1996, Spano and Freilich 2009) and situational crime prevention (Clarke 1980, Clarke 2005) that show that there is less rule breaking when there are less practical opportunities to do so. We used these insights to study whether the opportunity to violate the measures predicted compliance.

The sixth type of factor with a potential influence on compliance is people's impulsivity. The questionnaire included this measure in light of criminological findings that show that high levels of impulsivity predict deviant and rule breaking behavior (Gottfredson and Hirschi 1990, Pratt and Cullen 2000, 2005, Pratt and Llouyd 2021 (forthcoming), Vazsonyi, Mikuška, and Kelley 2017). We assessed whether higher impulsivity predicted compliance.

The seventh type of factor with a potential influence on compliance is descriptive social norms. Research shows that the more people see others comply with rules or requests, the 
more likely they will comply themselves. Research additionally shows that the more people see others violate or disobey, the more likely they will follow suit (Cialdini et al. 2006, Cialdini and Goldstein 2004, Goldstein, Cialdini, and Griskevicius 2008, Schultz et al. 2007). We assessed whether perceptions of how others follow the rules predicted respondents' own compliance.

The eighth type of factor with a potential influence on compliance is obligation to obey the law ("OOL") and procedural justice ("PJ"). This follows from a large body of work in psychology and criminology that shows that people who feel more obligated to obey the law are more likely to comply. Naturally, one may feel obligated to obey the law for a variety of reasons. On the one hand, OOL has a normative dimension; people voluntarily obey the rules if they have been made and enforced in a procedurally just way by a properly-established authority (Fine et al. 2020, Fine et al. 2016, Tyler 2017, Tyler 1997, 2006, Nagin and Telep 2017). Studies of OOL have found that when people think that such authorities who create and enforce rules do so in a procedurally fair and just manner, there is heightened OOL (Tyler 2017, Tyler 1997, 2006, Walters and Bolger 2019, Nagin and Telep 2017). Yet there is also a non-normative dimension to OOL, which exists when people have a sense to of duty to obey the rules out of a sense of coercion, thinking that they have no other choice but to obey. Here a key element is that people may see an obligation to obey the rules because they fear the authorities (Posch et al. 2020). We used these insights to study whether normative obligation to obey the law (Norm-OOL), non-normative obligation to obey the law (NonNOOL), and procedural justice (PJ) predicted higher compliance.

The ninth type of factor with a potential influence on compliance is people's political orientation. People increasingly live in echo-chambers, where they get news from traditional 
and social media sources which are aligned with a particular political orientation (Prior 2013, Baum and Groeling 2008, Fletcher and Nielsen 2017, Spohr 2017). These echo chambers can determine the way people learn about the pandemic and the measures taken to contain it. As such, their political orientation may come to determine how they view the measures, the authorities (Fine, Rowan, and Simmons 2019) and eventually, whether they comply. This line of argumentation can also be found in an earlier COVID-19 study, which found that US political partisanship was the most important predictor of policy preferences and health behavior before more restrictive stay at home measures were in place (Kushner Gadarian, Wallace Goodman, and Pepinsky 2020). We assessed whether political orientation predicted compliance.

\section{Sample}

\section{Method}

Participants $(N=600)$ were recruited through the online platform Prolific Academic. Data collection took place on April 3, 2020. Participants were eligible if they were U.S. residents and had lived in a state that on or before April $1^{\text {st }}, 2020$ (i.e., at least 2 days prior to the study's initiation): 1) had issued a stay at home or shelter in place directive, or 2) where over 50 percent of the state's population was subject to such a directive. As a result of the inclusion criteria, the study sampled participants in 35 of the 50 states in the U.S (Appendix). Participants were paid $\$ 3.00$ for participation. 25 participants were excluded because they provide professional care for COVID-19 patients, and seven participants were excluded because they failed the attention check. ${ }^{16}$ Table 1 shows the characteristics of the final sample $(N=570)$. 
Table 1.

Sample characteristics for the United States $(N=570)$.

\begin{tabular}{ll}
\hline & Mean $(S D)$ \\
\hline Age & $34.46(12.46)$ \\
Gender & \\
Female & $51.6 \%$ \\
Male & $46.8 \%$ \\
Other (non-binary) & $1.6 \%$ \\
Race/Ethnicity & \\
White & $73.3 \%$ \\
Black / African American & $7.5 \%$ \\
Asian / Pacific Islands & $10.2 \%$ \\
Hispanic / Latino & $6.0 \%$ \\
Other & $2.1 \%$ \\
Education & \\
No diploma & $0.9 \%$ \\
High school degree & $34.0 \%$ \\
College degree and higher & $65.1 \%$ \\
Political orientation & \\
$\quad$ Very progressive & $31.9 \%$ \\
$\quad$ Slightly progressive & $38.2 \%$ \\
Slightly conservative & $18.9 \%$ \\
Very conservative & $6.5 \%$ \\
\hline Nb. Political orientation - percentages may not add up \\
to 100\% as subjects could select the option to "prefer \\
not to say".
\end{tabular}

\section{Materials}

Control variables. The following descriptive statistics were recorded: age, gender, nationality, information on residency (country, state, city), education, household residents (total number and number of dependents), race/ethnicity, insurance status, and socioeconomic status before and after COVID-19 (MacArthur Scale of Subjective Social Status; Adler et al. 2000). Furthermore, participants indicated whether they provided professional care for COVID-19 patients, whether they visited friends or family over the age of 75 on a regular basis prior to the outbreak of the virus, and whether they or anyone they knew had underlying health issues that made them more at-risk for contracting COVID-19. Finally, participants were asked to indicate their trust in science on a single item taken from McCright et al. (2013), on a 5-point Likert scale ranging from (1) "completely distrust" to (5) "completely trust." Trust in media reporting was questioned similarly to trust in science. 
Compliance with COVID-19 measures. Compliance was measured with regard to two main COVID-19 mitigation measures: social distancing and stay at home. Four items $(\alpha=.75)$ measured whether participants complied with social distancing. Compliance with staying at home was measured with a single item. Participants answered a single item on a 7-point Likert scale ranging from (1) "never" to (7) "always.” For social distancing, three items were reverse scored. Mean scores were calculated both for social distancing and stay at home measures together $(\alpha=.76)$ and for the two measures separately. Higher values indicate greater compliance with these COVID-19 mitigation measures.

Substantive moral support. Substantive moral support was measured on three subscales: perceived threat, specific moral alignment, and support for current policies.

Perceived threat. Perceived threat was measured using three items $(\alpha=.89)$ on which participants indicated to what extent they believed COVID-19 was a threat to themselves or others, using a 7-point Likert scale ranging from (1) "very strongly disagree" to (7) "very strongly agree."

Specific moral alignment. Specific moral alignment was measured using two items ( $\alpha$ $=.96$ ) on which participants indicated to what extent they believed people should follow these COVID-19 mitigation measures, using a 7-point Likert scale ranging from (1) "very strongly disagree" to (7) "very strongly agree."

Support for current policies. Support for current policies was measured using three items $(\alpha=.28)$ on which participants indicated to what extent they supported the authorities in adopting these COVID-19 mitigation measures, using a 7-point Likert scale ranging from (1) "very strongly disagree" to (7) "very strongly agree." One item was reverse coded. The mean score was calculated, and higher values indicate more support for the authorities in adopting these COVID-19 measures. One item correlated poorly. If removed, Cronbach's alpha rose to $\alpha=.85$, so it was decided to exclude this item from further analyses. 
Costs of compliance and strain. Costs of compliance and strain were measured on two sub-scales: costs of compliance and negative emotions.

Costs of compliance. Participants indicated on five items $(\alpha=.78)$ how likely it was that compliance with these COVID-19 mitigation measures would have a negative impact on them. Participants answered on a 7-point Likert scale ranging from (1) "extremely unlikely" to (7) "extremely likely."

Negative emotions. Negative emotions due to COVID-19 was measured on six items $(\alpha=.88)$ assessing different negative emotions, rated on a 7-point Likert scale ranging from (1) "very strongly disagree" to (7) "very strongly agree." Means were calculated, and higher values indicated higher negative emotions.

Deterrence. Deterrence was measured for the two COVID-19 mitigation measures separately. Two items (social distancing $\alpha=.71$, stay at home $\alpha=.84$, combined $\alpha=.87$ ) measured certainty of apprehension and punishment for violating these COVID-19 measures, answered on a 7-point Likert scale ranging from (1) "extremely improbable" to (7) "extremely probable." Furthermore, for severity of punishment, participants indicated how much suffering would be inflicted if they were punished for violating each of the two COVID-19 measures (social distancing and stay at home combined $\alpha=.88$ ). Responses were recorded using a 6point Likert scale ranging from (1) "extreme suffering" to (6) "no suffering at all." Lower scores indicated higher suffering.

Capacity to comply. The capacity to comply was measured using two sub-scales: practical capacity to comply and perceived clarity of such measures.

Practical capacity to comply. Three items $(\alpha=.60)$ measured to what extent participants were practically able to comply with these COVID-19 mitigation measures, on a 7-point Likert scale ranging from (1) "very strongly disagree" to (7) "very strongly agree." One item correlated poorly ( $\alpha=.68$ if deleted). This item was excluded from further analyses. 
Perceived clarity of current measures. Furthermore, participants were asked whether the COVID-19 measures were clear to them ("The measures authorities have adopted to reduce the spread of the Coronavirus are...") and answered on a 7-point Likert scale ranging from (1) "extremely unclear" to (7) "extremely clear." Higher scores indicated greater clarity.

Opportunity to violate. Five items $(\alpha=.82)$ measured to what extent participants had the opportunity to violate these COVID-19 mitigation measures. Responses were recorded using a 7-point Likert scale ranging from (1) "very strongly disagree" to (7) "very strongly agree."

Impulsivity. Impulsivity was measured using a subset of five items $(\alpha=.76)$ taken from the 8-item impulse control subscale from the Weinberger Adjustment Inventory (WAI; Weinberger and Schwartz 1990). The items were answered on a 5-point Likert scale ranging from (1) "false" to (5) "true." One item was reverse coded, and means were calculated. Higher scores indicated greater impulsivity.

Descriptive social norms. Participants rated the extent to which people they know comply with these COVID-19 mitigation measures (one item for each measure, $\alpha=.94$ ), on a 7-point Likert scale ranging from (1) "very strongly disagree" to (7) "very strongly agree." Higher scores indicated participants thought people they know are highly compliant with mitigation measures.

Obligation to obey the law (OOL) and Procedural Justice (PJ). To assess OOL and PJ, the survey has three sub-scales: normative obligation to obey the law, non-normative obligation to obey the law, and procedural justice.

Normative obligation to obey: Normative obligation to obey was measured with a single item, "I feel like it is sometimes okay to break the law," on a 7-point Likert scale ranging from (1) "strongly agree" to (7) "strongly disagree." This item was created for the current study 
based on existent work (e.g., (Estévez and Emler 2010, Reisig, Bratton, and Gertz 2007, Fine et al. 2020). Higher scores indicated greater normative obligation to obey the law.

Non-normative obligation to obey: Non-normative obligation was measured using a single item, "I only obey the authorities handling the Coronavirus because I am afraid of them" (adapted for COVID19 following (Posch et al. 2020, Tankebe, Reisig, and Wang 2016)). This item was measured on a 7-point Likert scale ranging from (1) "very strongly disagree" to (7) "very strongly agree." Higher scores indicated greater non-normative obligation to obey.

Procedural justice (PJ). Procedural justice was measured using items adapted from prior measures of procedural justice used in several studies of the police (Baker and Gau 2018, Gau 2014, Tyler 1997, Wolfe et al. 2016). Three items $(\alpha=.93)$ measured PJ in creating these COVID-19 mitigation measures. Four items $(\alpha=.93)$ measured PJ in enforcing these COVID19 mitigation measures. The items were answered on a 7-point Likert scale ranging from (1) "very strongly disagree" to (7) "very strongly agree." The seven items for PJ in creating the and enforcing the measures were combined in a single PJ scale $(\alpha=.95)$. Higher values indicated greater procedural justice.

Political orientation. Political orientation was measured with a single item adapted from prior research (Hasson et al. (2018), Fine, Rowan, and Simmons (2019), Wojcik et al. (2015)). The question was answered on a 4-point scale, ranging from (1) "very progressive" to (4) "very conservative." Participants could also respond with "prefer not to say;" these participants were excluded from the analyses that included political orientation. ${ }^{17}$

\section{Results}

\section{Descriptive statistics.}

Tables 2 and 3 respectively show the descriptive statistics of the control and independent variables. 
Table 2.

Descriptive statistics of the control variables $(N=570)$.

\begin{tabular}{|c|c|c|}
\hline & Mean $(S D)$ & \\
\hline$N$ Household & $2.75(1.44)$ & \\
\hline$N$ Children & $.41(.88)$ & \\
\hline \multicolumn{3}{|l|}{ Insurance Status } \\
\hline Uninsured & $15.1 \%$ & \\
\hline Private & $60.3 \%$ & \\
\hline Public & $24.6 \%$ & \\
\hline SES pre-COVID-19 & $5.16(1.76)$ & \\
\hline SES post-COVID-19 & $5.02(1.93)$ & \\
\hline Friends/Family 75+ & $26.8 \%$ & \\
\hline Health issues self & $20.2 \%$ & \\
\hline Health issues other & $68.1 \%$ & \\
\hline Trust in science & $4.27(.87)$ & Scale $1-5$ \\
\hline Trust in media & $2.81(1.21)$ & Scale 1-5 \\
\hline
\end{tabular}

Table 3.

Descriptive statistics of the independent variables $(N=570)$.

\begin{tabular}{lccc}
\hline & Mean & SD & \\
\hline Substantive moral alignment & & & \\
$\quad$ Perceived threat & 5.33 & 1.45 & Scale 1-7 \\
$\quad$ Specific moral alignment & 6.26 & 1.39 & Scale 1-7 \\
$\quad$ Support for current policies & 3.28 & 1.42 & Scale 1-7 \\
Costs of compliance & 4.24 & 1.40 & Scale 1-7 \\
$\quad$ Negative emotions & 4.55 & 1.25 & Scale 1-7 \\
Deterrence & & & \\
$\quad$ Certainty & 3.28 & 1.32 & Scale 1-6 \\
$\quad$ Severity & 3.98 & 1.19 & Scale 1-7 \\
Capacity to comply & & & \\
$\quad$ Practical capacity to comply & 5.85 & 1.20 & Scale 1-7 \\
$\quad$ Clarity current measures & 5.85 & 2.48 & Scale 1-7 \\
Opportunity to violate & 3.65 & 1.41 & Scale 1-7 \\
Impulsivity & 2.01 & .76 & Scale 1-5 \\
Descriptive social norms & 5.46 & 1.28 & Scale 1-7 \\
Obligation to obey the law and Procedural Justice & & & \\
$\quad$ Normative OOL & 4.43 & 1.71 & Scale 1-7 \\
$\quad$ Non-normative OOL & 2.62 & 1.51 & Scale 1-7 \\
$\quad$ Procedural Justice & 4.20 & 1.45 & Scale 1-7 \\
Political orientation & 2.00 & .90 & Scale 1-4 \\
\hline
\end{tabular}

Nb. Political orientation $-n=545$. 
Table 4 shows the descriptive statistics of the dependent variable that reflects compliance with the COVID-19 mitigation measures. For all items, means are considerably large, indicating that overall, participants self-reported high rates of compliance.

Table 4.

Descriptive statistics of compliance with COVID-19 measures (Likert 1-7, never-always) $(N=570)$.

\begin{tabular}{llc}
\hline Item & Mean & SD \\
\hline Since the authorities took measures to contain the Coronavirus: & \\
1. I still meet people outside of my direct household.^ & 6.32 & 0.99 \\
2. I keep a safe distance from people outside of my direct household. & 6.22 & 1.13 \\
3. I still visit others (friends, relatives) outside of my direct household.^ & 6.41 & 0.94 \\
4. I still allow others (friends, relatives) to visit my direct household.^ & 6.38 & 1.11 \\
5. I have stayed at home after I was ordered to do so, apart from engaging in & 6.28 & 1.28 \\
$\quad$ essential activities (e.g., grocery shopping, medical appointments). & & \\
\hline Combined measure & 6.32 & 0.78 \\
\hline
\end{tabular}

$\mathrm{Nb}^{\wedge}-$ Reverse scored. Item $5-N=569$.

\section{Correlations}

Table 5 reports the correlation matrix of the control variables and the dependent variable. Table 6 shows the correlations between the independent variables and the dependent variable. 
Table 5.

Kendall's tau correlations with control variables $(N=570)$.

\begin{tabular}{|c|c|c|c|c|c|c|c|c|c|c|c|c|c|}
\hline & $\underset{8}{8}$ & 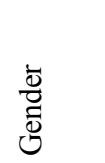 & 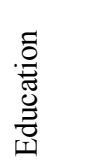 & 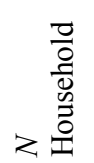 & 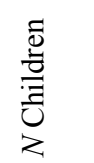 & 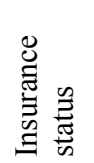 & 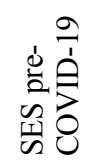 & 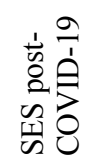 & 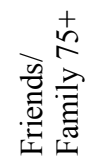 & 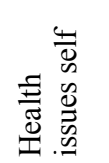 & 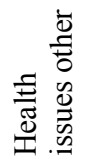 & 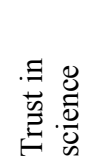 & 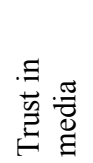 \\
\hline Gender & .067 & & & & & & & & & & & & \\
\hline Education & $.193^{* *}$ & .031 & & & & & & & & & & & \\
\hline$N$ Household & $-.123^{* *}$ & $.087^{*}$ & $-.140^{* *}$ & & & & & & & & & & \\
\hline$N$ Children & $.171^{* *}$ & .079 & .044 & $.424^{* *}$ & & & & & & & & & \\
\hline Insurance status & .012 & -.026 & -.014 & -.001 & .006 & & & & & & & & \\
\hline SES pre-COVID-19 & -.008 & .026 & $.297^{* *}$ & $.077^{*}$ & $.084^{*}$ & .011 & & & & & & & \\
\hline SES post-COVID-19 & -.005 & -.017 & $.303^{* *}$ & .058 & .059 & .005 & $.825^{* *}$ & & & & & & \\
\hline Friends/Family 75+ & .060 & -.039 & $.078^{*}$ & .032 & .043 & .039 & $.120^{* *}$ & $.083^{*}$ & & & & & \\
\hline Health issues self & $.118^{* *}$ & $.137^{* *}$ & -.053 & -.020 & .043 & .004 & $-.118^{* *}$ & $-.146^{* *}$ & .041 & & & & \\
\hline Health issues other & $.095^{* *}$ & $.180^{* *}$ & .003 & .014 & -.067 & .070 & $-.079^{*}$ & $-.092^{*}$ & $.194^{* *}$ & $.260^{* *}$ & & & \\
\hline Trust in science & .012 & .050 & $.123^{* *}$ & -.019 & -.041 & .000 & $.115^{* *}$ & $.124^{* *}$ & .010 & -.037 & $.085^{*}$ & & \\
\hline Trust in media & $.146^{* *}$ & .050 & $.071^{*}$ & -.063 & -.023 & $.110^{* *}$ & $.086^{*}$ & $.068^{*}$ & .060 & .038 & .065 & $.248^{* *}$ & \\
\hline Compliance & $.064^{*}$ & $.249^{* *}$ & .054 & .021 & -.015 & -.013 & .051 & .041 & -.011 & $.136^{* *}$ & $.143^{* *}$ & $.169^{* *}$ & $.113^{* *}$ \\
\hline
\end{tabular}


Table 6.

Kendall's tau correlations with the independent variables $(N=570)$.

\begin{tabular}{|c|c|c|c|c|c|c|c|c|c|c|c|c|c|c|c|c|}
\hline & 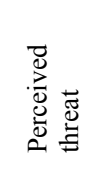 & 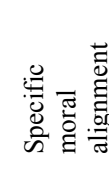 & 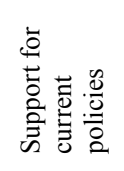 & 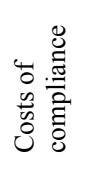 & 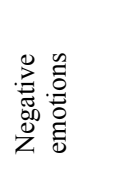 & 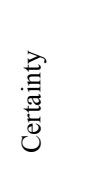 & 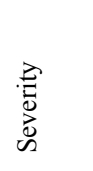 & 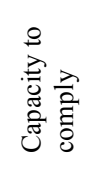 & 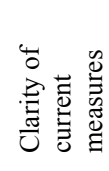 & 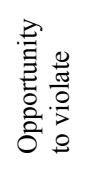 & 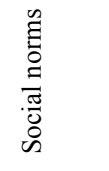 & 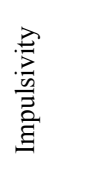 & 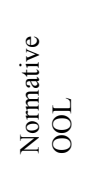 & ن & 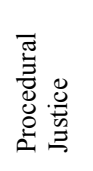 & 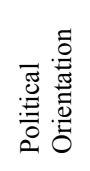 \\
\hline Specific moral alignment & $.483^{* *}$ & & & & & & & & & & & & & & & \\
\hline Support for current policies & $-.144^{* *}$ & $-.177^{* *}$ & & & & & & & & & & & & & & \\
\hline Costs of compliance & .045 & .032 & -.030 & & & & & & & & & & & & & \\
\hline Negative emotions & $.175^{* *}$ & $.124^{* *}$ & $-.136^{* *}$ & $.264^{* *}$ & & & & & & & & & & & & \\
\hline Certainty & -.022 & .009 & $.092^{* *}$ & $.102^{* *}$ & .026 & & & & & & & & & & & \\
\hline Severity & .000 & .031 & .033 & $-.075^{*}$ & $-.129^{* *}$ & $-.224^{* *}$ & & & & & & & & & & \\
\hline Capacity to comply & $.168^{* *}$ & $.289^{* *}$ & -.027 & -.019 & .054 & .004 & -.028 & & & & & & & & & \\
\hline Clarity current measures & -.001 & .019 & $.274^{* *}$ & $-.067^{*}$ & $-.132^{* *}$ & .058 & .062 & $.163^{* *}$ & & & & & & & & \\
\hline Opportunity to violate & -.046 & $-.069^{*}$ & $-.061^{*}$ & $-.059^{*}$ & -.012 & $-.149^{* *}$ & .056 & $-.166^{* *}$ & $-.096^{* *}$ & & & & & & & \\
\hline Social norms & .032 & $.135^{* *}$ & .016 & -.034 & -.032 & .041 & -.030 & $.234^{* *}$ & $.110^{* *}$ & $-.107^{* *}$ & & & & & & \\
\hline $\begin{array}{l}\text { Impulsivity } \\
\text { Obligation to obey the law }\end{array}$ & -.043 & $-.111^{* *}$ & -.011 & .051 & $.091^{* *}$ & -.004 & -.008 & $-.135^{* *}$ & $-.083^{* *}$ & $.071^{*}$ & $-.117^{* *}$ & & & & & \\
\hline $\begin{array}{l}\text { and Procedural ustice } \\
\text { Normative OOL }\end{array}$ & $.110^{* *}$ & $.093^{* *}$ & $.128^{* *}$ & -.046 & -.034 & .039 & -.006 & $.085^{* *}$ & $.174^{* *}$ & $-.149^{* *}$ & $.079^{*}$ & $-.181^{* *}$ & & & & \\
\hline Non-normative $O O L$ & $-.123^{* *}$ & $-.170^{* *}$ & $.112^{* *}$ & $.085^{* *}$ & .035 & $.064^{*}$ & $-.103^{* *}$ & $-.148^{* *}$ & -.061 & .002 & $-.162^{* *}$ & $.173^{* *}$ & -.015 & & & \\
\hline Procedural Justice & .012 & -.037 & $.362^{* *}$ & -.027 & $-.116^{* *}$ & .048 & .041 & .059 & $.311^{1 * *}$ & $-.110^{* *}$ & $.090^{* *}$ & -.045 & $.204^{* *}$ & -.056 & & \\
\hline Political Orientation & $-.149^{* *}$ & $-.172^{* *}$ & $.290^{* *}$ & -.060 & $-.186^{* *}$ & .044 & .011 & -.069 & $.090^{*}$ & .001 & -.057 & -.018 & $.124^{* *}$ & .062 & $.231^{* *}$ & \\
\hline Compliance & $.239^{* *}$ & $.342^{* *}$ & $-.063^{*}$ & .031 & $.102^{* *}$ & .035 & -.011 & $.347^{* *}$ & $.119^{* *}$ & $-.144^{* *}$ & $.189^{* *}$ & $-.209^{* *}$ & $.138^{* *}$ & $-.153^{* *}$ & .020 & $-.122^{* *}$ \\
\hline
\end{tabular}




\section{Regression analysis.}

We performed a series of ordinary least-squares regressions using the compliance measure as the dependent variable. For each predictor, a separate regression model was estimated, in which we controlled for a fixed set of control variables (i.e., those that had shown significant correlations with compliance [Table 5]: age, gender, health issues self, health issues other, trust in science, and trust in media). Regressions were adjusted for heteroscedasticity using Huber/White robust standard error estimation. Table 7 shows the results of the OLS regressions.

Table 7.

Separate OLS regression analyses of compliance $(N=569)$, adjusted for control variables.

\begin{tabular}{|c|c|c|c|}
\hline & B & SE & $\mathbf{R S q}$ \\
\hline \multicolumn{4}{|l|}{ Substantive moral support } \\
\hline Perceived threat & $.15 * * *$ & .03 & .20 \\
\hline Specific Moral Alignment & $.17 * * *$ & .04 & .21 \\
\hline Support for current policies & -.02 & .02 & .13 \\
\hline Costs of compliance & .04 & .02 & .13 \\
\hline Negative emotions & $.08 *$ & .3 & .14 \\
\hline \multicolumn{4}{|l|}{ Deterrence } \\
\hline Certainty & .04 & .02 & .13 \\
\hline Severity & -.02 & .03 & .13 \\
\hline Capacity to comply & $.17 * * *$ & .03 & .19 \\
\hline Clarity current measures & .02 & .01 & .13 \\
\hline Opportunity to violate & $-.10 * * *$ & .02 & .16 \\
\hline Impulsivity & $-.22 * * *$ & .05 & .17 \\
\hline $\begin{array}{l}\text { Descriptive social norms } \\
\text { Obligation to obey the law and } \\
\text { Procedural Justice }\end{array}$ & $.10 * * *$ & .03 & .15 \\
\hline Normative $O O L$ & $.04 *$ & .02 & .13 \\
\hline Non-normative $O O L$ & $-.08 * *$ & .03 & .15 \\
\hline Procedural justice & .02 & .02 & .13 \\
\hline Political orientation & -.07 & .04 & .14 \\
\hline
\end{tabular}

The data shows that several independent variables were significantly associated with compliance. We found positive, significant associations with compliance for perceived threat, moral belief, negative emotions, practical capacity to comply, descriptive social norms, and 
normative OOL. We found negative, significant associations with compliance for opportunity to violate, impulsivity, and non-normative OOL. For all other independent variables, no significant associations with compliance were observed.

To complement these separate regression models, we also conducted a series of stepwise regressions, in which multiple predictors were included within the same model. This approach allowed us to examine whether their associations with compliance remained, while taking into account the effects of other independent variables. For these models, collinearity statistics indicated no issues with multicollinearity (all VIFs $\leq 2.25$; all tolerances $\geq .44$ ).

In the first step (model 0), we included only the control variables that significantly correlated with compliance (see Table 8). Results indicated that gender, health issues others, trust in science, and trust in media were significantly associated with compliance. More specifically, women, people who knew someone with health issues, and people with higher levels of trust in science and media reporting showed greater compliance with COVID-19 mitigation measures. Age and personal health issues were not related to compliance.

In model 1, we added the measures of substantive moral support (perceived threat, specific moral alignment, and support for current policies), costs of compliance (cost and negative emotions), and impulsivity. Results indicated that specific moral alignment, negative emotions, and impulsivity showed significant associations with compliance; participants who more strongly believed people should follow the COVID-19 mitigation measures, who experienced more negative emotions, and who were less impulsive, showed greater compliance with the COVID-19 mitigation measures. Relative to model 0, the percentage of explained variance in compliance increased from $13 \%$ to $28 \%$. Perceived threat, support for current policies, and costs of compliance were unrelated to compliance.

In model 2, we added the measures of deterrence (certainty and severity) and descriptive social norms. Results indicated that descriptive social norms were significantly 
associated with compliance; people who reported more compliant descriptive social norms showed greater compliance. Relative to model 1, the percentage of explained variance in compliance increased from $28 \%$ to $31 \%$. Deterrence was unrelated to compliance.

In model 3, we entered the measures of capacity to comply (practical capacity and clarity of measures) and opportunity to violate. Results indicated that these measures all showed significant associations with compliance; people that had greater ability to comply, perceived the measures to be clearer, and had less opportunity to violate. All showed greater compliance with the COVID-19 mitigation measures. Relative to model 2, the percentage of explained variance in compliance increased from $31 \%$ to $35 \%$.

In model 4, we entered the measures of obligation to obey the law (normative OOL, non-normative OOL, and PJ). Results indicated that non-normative OOL was significantly associated with compliance; people that reported less non-normative OOL showed greater compliance. In other words, the more participants indicated that they only obey the authorities handling the Coronavirus because they are afraid of them, the less they complied. Relative to model 3, the percentage of explained variance in compliance increased from $35 \%$ to $36 \%$. Normative obligation to obey the law and procedural justice were not related to compliance.

Finally, in model 5, we entered political orientation. The results revealed that political orientation was not associated with compliance. 
Table 8.

Step-wise regression models of compliance $(N=569)$.

\begin{tabular}{|c|c|c|c|c|c|c|}
\hline & $\begin{array}{l}\text { Model } 0 . \\
\text { Baseline } \\
\text { model } \\
\text { (controls } \\
\text { only) }\end{array}$ & $\begin{array}{l}\text { Model 1. } \\
\text { + Substantive } \\
\text { moral support, } \\
\text { Costs of } \\
\text { compliance, } \\
\text { Impulsivity }\end{array}$ & $\begin{array}{l}\text { + Deterrence, } \\
\text { Social Norms }\end{array}$ & $\begin{array}{l}\text { + Capacity, } \\
\text { opportunity }\end{array}$ & $\begin{array}{l}+ \text { Obligation to } \\
\text { obey the law }\end{array}$ & $\begin{array}{l}+ \text { Political } \\
\text { orientation }\end{array}$ \\
\hline & $\mathrm{b}(\mathrm{SE})$ & $\mathrm{b}(\mathrm{SE})$ & $\mathrm{b}(\mathrm{SE})$ & $\mathrm{b}(\mathrm{SE})$ & $\mathrm{b}(\mathrm{SE})$ & $\mathrm{b}(\mathrm{SE})$ \\
\hline Age & $.00(.00)$ & $-.00(.00)$ & $-.00(.00)$ & $.00(.00)$ & $-.00(.00)$ & $.00(.00)$ \\
\hline \multicolumn{7}{|l|}{ Gender } \\
\hline i. female & $.38 * * *(.06)$ & $.28 * * *(.06)$ & $.28 * * *(.06)$ & $.26 * * *(.06)$ & $.25 * * *(.06)$ & $.24 * * *(.06)$ \\
\hline ii. non-binary & $.14(.28)$ & $.01(.23)$ & $.04(.20)$ & $.11(.23)$ & $.14(.23)$ & $.08(.25)$ \\
\hline Health (self) & $.10(.07)$ & $.07(.07)$ & $.08(.07)$ & $.04(.07)$ & $.03(.07)$ & $.01(.08)$ \\
\hline Health (others) & $.17 *(.07)$ & $.07(.07)$ & $.05(.06)$ & $.06(.06)$ & $.06(.06)$ & $.07(.07)$ \\
\hline Trust in science & $.10 *(.04)$ & $.03(.04)$ & $.01(.04)$ & $.01(.04)$ & $.00(.04)$ & $.00(.04)$ \\
\hline Trust in media & $.07 *(.03)$ & $.04(.03)$ & $.04(.03)$ & $.03(.03)$ & $.03(.03)$ & $.03(.03)$ \\
\hline Perceived threat & & $.06(.04)$ & $.07(.04)$ & $.07(.04)$ & $.06(.04)$ & $.06(.04)$ \\
\hline \multicolumn{7}{|l|}{ Specific moral } \\
\hline alignment & & $.12 * *(.04)$ & $.11 * *(.04)$ & $.10 * *(.04)$ & $.10 * *(.04)$ & $.10 * *(.04)$ \\
\hline \multicolumn{7}{|l|}{ Support for current } \\
\hline policies & & $-.01(.02)$ & $-.01(.02)$ & $-.03(.02)$ & $-.03(.02)$ & $-.02(.02)$ \\
\hline \multicolumn{7}{|l|}{ Costs of } \\
\hline compliance & & $.02(.02)$ & $.02(.02)$ & $.02(.02)$ & $.02(.02)$ & $.02(.02)$ \\
\hline Negative emotions & & $.08 * *(.03)$ & $.09 * *(.03)$ & $.09 * *(.03)$ & $.09 * *(.03)$ & $.09 * *(.03)$ \\
\hline Impulsivity & & $-.24 * * *(.04)$ & $-.22 * * *(.04)$ & $-.20 * * *(.04)$ & $-.19 * * *(.04)$ & $-.19 * * *(.05)$ \\
\hline \multicolumn{7}{|l|}{ Deterrence - } \\
\hline Certainty & & & $.02(.02)$ & $.01(.02)$ & $.01(.02)$ & $.02(.02)$ \\
\hline Severity & & & $.00(.02)$ & $.01(.02)$ & $-.00(.02)$ & $-.00(.03)$ \\
\hline Social norms & & & $.09 * * *(.02)$ & $.07 * *(.02)$ & $.06^{* *}(.02)$ & $.06^{* *}(.02)$ \\
\hline \multicolumn{7}{|l|}{ Practical capacity } \\
\hline to comply & & & & $.10 * * *(.03)$ & $.09 * * *(.03)$ & $.09 * *(.03)$ \\
\hline Clarity of measures & & & & $.02(.01)$ & $.02(.01)$ & $.02(.01)$ \\
\hline \multicolumn{7}{|l|}{ Opportunity to } \\
\hline violate & & & & $-.05 * *(.02)$ & $-.05 * *(.02)$ & $-.05 * *(.02)$ \\
\hline \multicolumn{7}{|l|}{ Normative } \\
\hline \multicolumn{7}{|l|}{ obligation to obey } \\
\hline the law & & & & & $.01(.02)$ & $.01(.02)$ \\
\hline \multicolumn{7}{|l|}{ Non-normative } \\
\hline OOL & & & & & $-.05 *(.02)$ & $-.05 *(.03)$ \\
\hline Procedural justice & & & & & $.01(.02)$ & $.01(.02)$ \\
\hline Political orientation & & & & & & $-.03(.04)$ \\
\hline $\mathbf{R S q}$ & .13 & .28 & .31 & .35 & .36 & .35 \\
\hline$R S q$ (change) & .13 & .15 & .03 & .04 & .01 & -.01 \\
\hline
\end{tabular}

$\mathrm{Nb} .{ }^{*}$ - Correlation is significant at the .05 level. ${ }^{*}$ - Correlation is significant at the .01 level. *** - Correlation is significant at the .001 level. Model $5-N=545$. 


\section{Discussion}

This study analyzed compliance with COVID-19 mitigation measures in the US. The first finding of this study is that self-reported compliance was relatively high. Most people indicated that they were nearly always compliant. This is in line with objective data we have about the effects of the COVID-19 mitigation measures on behavior in the US from the Google COVID-19 Community Mobility Report. ${ }^{18}$ The Google data provides a helicopterview picture, using cell-phone location data to track changes in people's mobility. It shows large reductions in retail and recreational activities, as well as in the usage of public transit, and visits to workplaces. ${ }^{19}$ Our data shows a more fine-grained picture of this massive behavioral change. It allows us to understand whether people themselves think they keep a safe distance, whether they still meet people outside, and whether they still meet with friends and relatives outside of their direct household. In sum, the study confirms that compliance with the COVID-19 mitigation measures within the US has been high thus far.

The following question is why people have complied thus far. This key question will allow us to better understand which policies are necessary to maintain compliance in the future. We found mixed results about whether people's overall substantive moral support for the measures play a role in their compliant behavior. On one hand, we found a significant association between whether participants morally believed that people should follow the measures and their actual compliant behavior. However, we did not find such an association between whether people feared the virus (perceived threat), or generally supported the measures that were adopted, and thought they were consistent, adequate, and proportional, and their compliant behavior. This shows that what really matters for compliance is not whether people think the measures are appropriate or necessary to protect themselves or 
loved ones, but rather whether they hold the belief that morally people should comply. Overall, it shows that at this time, moral support for the measures does play a role in compliance.

The data further show that people's perceptions of personal costs of compliance (e.g., impact on personal income, personal employment, or personal social relationships) are not associated with compliance. Thus, at this point, in which measures have been recently implemented, people who perceive the personal costs to be much higher are not significantly less or more likely to comply than those with lower costs. Furthermore, the data did show that people who had negative emotions, as they are now subject to stay at home and social distancing measures, are significantly more likely to comply. When we analyze these findings together, they are not in line with what we had expected based on prior research on strain and deviancy (Agnew 1992, 2006, Agnew et al. 2002, Agnew and White 1992, Baron 2004, Piquero and Sealock 2004, Botchkovar, Tittle, and Antonaccio 2009). One possible explanation may be that because this survey was taken when the measures were in place only for a short period of time, the costs of compliance had not strongly materialized yet, and thus might not have impacted compliance. It may well be that as the measures stay in place longer or should they be lifted and reinstituted to deal subsequent resurgences of infections, the costs of compliance and negative emotions may begin to negatively affect compliance as strain theory suggests.

The data showed that self-control was negatively associated with compliance. This is in line with our expectations, based on the study of self-control in offending behavior (Gottfredson and Hirschi 1990, Pratt and Cullen 2000, 2005, Pratt and Llouyd 2021 (forthcoming), Vazsonyi, Mikuška, and Kelley 2017). This shows that, within the American population, there are individual differences in compliance. People who are more impulsive are less likely 
to follow the measures. This is important knowledge, as it supports measures that make it practically harder to refrain from social distancing, for instance the measures in New York City where basketball hoops were removed.

The data did not show that deterrence was associated with compliance. This is not entirely surprising as existing research shows that there is inconclusive evidence that stricter punishment alone can deter offending behavior (Nagin 2013, Nagin, Cullen, and Jonson 2009, Nagin and Pepper 2012, Simpson et al. 2014). Research shows that what matters most is the certainty of punishment; there is evidence that below a minimum threshold of certainty, punishment will not deter (Brown 1978, Chamlin 1991). Achieving such minimum certainty of detection and punishment for violating the COVID-19 mitigating measures will be challenging. The challenges will be especially pronounced in US, as there are no strong digital and social surveillance measures like, for example, in China. However, in the US there have been high levels of compliance without a significant association with deterrence. As such, compliance thus far seems to be voluntary, rather than enforced through deterrence threats.

The data further showed that what we think others are doing had an impact on our own compliant behavior. In this study, descriptive social norms were associated with compliance. The more Americans see others comply, the more likely they are to follow suit. This is in line with existing psychological research about social norms, which has shown the powerful influence social norms play in achieving compliance (Cialdini et al. 2006, Cialdini and Goldstein 2004, Goldstein, Cialdini, and Griskevicius 2008, Schultz et al. 2007). What is remarkable here is that in such a short period of time, the existing descriptive social norms have changed so fundamentally. Suddenly most people are staying at home, refraining from 
meeting people outside of their direct household, and maintaining social distance. The big questions are (1) what will happen when the measures are in place for a longer period of time, and (2) what will heightened violation of the measures mean. As the current association holds, this may spur a decline in compliant behavior.

The data also showed that compliance in the US is not just a free choice. People who are less practically able to comply with the measures are indeed less likely to maintain social distancing and/or stay at home. People who have more opportunity to violate the measures, for instance, in meeting with people outside their direct household, not maintaining social distance, or going outside for non-essential activities, are more likely to violate the measures. These findings are in line with our expectations (Cohen and Felson 1979, Osgood et al. 1996, Spano and Freilich 2009, Clarke 1980, Clarke 2005), and have important policy consequences. On one hand, these findings show that authorities and employers must do everything they can to ensure that people can work from home, maintain social distance, and conduct their lives indoors save for essential activities. On the other hand, it shows that measures that reduce opportunities for violation can help to sustain compliance. Here, we can think of the closing of public venues, reduction of access to parking at such venues, and the closing of non-essential businesses. In the long run, this can have dangerous consequences. It is neither socially nor economically not viable to keep societies and the economy as closed as they have been in this first period of social distancing and staying at home. With just a couple of weeks of stay at home measures, unemployment in the US has skyrocketed, with the Washington Post reporting on April 17 that 22 million people had lost their job, "wiping out a decade of job gains. ${ }^{" 20}$ When more opportunities arise to meet with others, the data suggests that it is likely that people will also start to refrain from complying with social distancing measures more. 
The data showed mixed results about how obligation to obey the law and procedural justice associated with compliance. We did not find that normative obligation to obey the law and procedural justice were associated with compliance in the US at this point, as we had expected based on existing studies of how OOL and PJ are associated with crime and lawviolating behavior (Fine et al. 2020, Fine et al. 2016, Tyler 2017, Tyler 1997, 2006, Nagin and Telep 2017, Walters and Bolger 2019). However, the results indicated that nonnormative obligation to obey authorities was negatively associated with compliance. The more people think they must obey authorities out of fear, the less likely they are to comply. This seems to indicate that for these Americans, the fear of authorities backfires, which results in less compliance and a form of resistance (Miller 1976, Quick and Stephenson 2007, Reich and Robertson 1979). The more individuals fear the authorities enforcing the measures, the more they disobey the measures, likely in a form of rebellion to authority they deem to be coercive.

Finally, the data did not show the expected association between political orientation and compliance. Here, our study differs from research about compliance with COVID-19 mitigation measures done before the stay at home and social distancing measures were adopted, where political orientation was one of the most important predictors (Kushner Gadarian, Goodman, and Pepinsky 2020). There are three possible reasons for this difference. First, our sample has a relatively higher number of progressives $(70.1 \%)$ and fewer conservatives $(25.4 \%)$ and this may have affected how political orientation was associated with compliance. However, given the large sample size, we do not believe that to be the full explanation. A second, and more probably possibility, is that the political divide in addressing the COVID-19 pandemic has shifted significantly in the period between March 
20-23, when the prior research was completed, and April 3 when the present study was conducted. In this short period of time, governors and mayors from across the political divide began to support and implement stronger measures. At the federal level, there was also an increased consensus for these measures. Third, within this time period, people's behavior and attitudes changed considerably and more rapidly than other variables, such as social norms and moral attitudes towards compliance with the measures. Social norms and moral views appear to shape compliant behavior more strongly than political orientation. Only time will tell whether this will remain true in light of the recent politically-laden protests in states like Michigan and Arizona. That is, it is possible that the impact of political views on compliance may be changing with time; initially, it may have been strongly associated with compliance during March, weakly associated during early April, and increasingly associated during midto-late April, exhibiting a U-shaped curve.

\section{Conclusion}

The COVID-19 mitigation measures have led to a fundamental shift in human behavior in the US. The present study analyzes what made Americans come to comply with the stay at home and social distancing measures. It shows that enforcement did not play a positive role, as compliance was not associated with deterrence and was negatively associated with a nonnormative obedience to authorities based on fear. Instead, compliance operated through two broad processes. First, compliance is shaped by people's capacity to obey the measures, their self-control, and their lack of opportunity to violate. As such, part of compliance is not shaped by people's choice, but rather by their own personal abilities and the context in which they lived. And second, compliance is shaped by people's intrinsic motivations, which 
determined the choices they could make, including substantive moral support, and social norms.

This study has several limitations. Although we used a diverse sample in terms of demographic variables (age, gender, race/ethnicity, political orientation, and geographical locations), we cannot claim it was representative of the American population as a whole. It might thus be possible that there are unobserved differences across states that have affected study outcomes (i.e., unobserved variable bias). Furthermore, we limited ourselves to analyzing multi-variate regressions for all controls and independent variables. We have not yet conducted interactions or models of sets of variables to understand how different variables may mediate others. Also, the study is limited as we used self-reported compliance data that may not necessarily reflect objective behavior. However, existing research shows that there can be strong concordance between self-reported and objective compliance measures when surveys are utilized, as the present study did (Garber et al. 2004, Bachmann et al. 1999, Dieltjens et al. 2013, Rauscher et al. 1993, Ridgers et al. 2012).

The study has several practical implications both for the short term and the long term. It shows that, at present, to sustain compliance authorities must focus more on interventions that enable compliance (for instance programs that support loss of income or enable working from home), obstruct non-compliance (by limiting access to public spaces and eliminating the opportunity for close social contacts), increase perceptions of social norms (by communicating how normal and widespread compliance is), as well as provide messages that strengthen moral support for the measures. Authorities must be careful when making deterrent and threatening statements. Not only are such statements not associated with greater 
compliance, they may even trigger a negative effect as non-compliance may increase when citizens base their obligation to obey out of fear.

For the long run, we speculate that maintaining current levels of social distancing will become increasingly difficult. It is likely that governments, in light of economic and societal demands, will lift some of the restrictions on public spaces, thereby increasing opportunities for people to gather. Unfortunately, opportunity to break rules was consistently associated with non-compliance, and lifting restrictions will inherently create opportunity. As people see the number of infections and deaths decrease as a result of the initial measures, they will likely have less substantive moral support for compliance with the measures. Also, we expect that the longer people have to maintain social distance and stay at home, the higher the costs of compliance will become. At some point, this may undermine their capacity to comply, as they potentially lose income or even housing. We speculate that at that point, the measures themselves may spur negative emotions, which will enable people to cope through offending. Once more people start to offend, social norms will start to shift and non-compliance may normalize.

Therefore, it is essential to track compliance responses to the COVID19 measures over the coming weeks and months. Here, we may help ensure that authorities take the right steps to continue to mitigate COVID-19. 
Appendix A. List of included states ${ }^{21}$

\begin{tabular}{|c|c|c|c|c|}
\hline STATE & COUNTY & MUNICIPALITY & DATE & $\begin{array}{l}\text { \% OF } \\
\text { STATE }\end{array}$ \\
\hline Alaska & & & $28-\mathrm{mrt}$ & \\
\hline Arizona & & & 31-mrt & \\
\hline California & & & $19-\mathrm{mrt}$ & \\
\hline Colorado & & & $26-\mathrm{mrt}$ & \\
\hline Connecticut & & & $23-\mathrm{mrt}$ & \\
\hline Delaware & & & 24-mrt & \\
\hline District of Columbia & & & 1-apr & \\
\hline Florida & & & & $52 \%$ \\
\hline & Alachua & & 24-mrt & \\
\hline & Broward & & $27-\mathrm{mrt}$ & \\
\hline & Hillsborough & & $27-\mathrm{mrt}$ & \\
\hline & Leon & & $25-\mathrm{mrt}$ & \\
\hline & Miami-Dade & & $25-\mathrm{mrt}$ & \\
\hline & Orange & & 26-mrt & \\
\hline & Osceola & & 26-mrt & \\
\hline & Palm Beach County & & $30-\mathrm{mrt}$ & \\
\hline & Pinellas & & 26-mrt & \\
\hline Hawaii & & & $25-\mathrm{mrt}$ & \\
\hline Idaho & & & $25-\mathrm{mrt}$ & \\
\hline Illinois & & & 21-mrt & \\
\hline Indiana & & & 24-mrt & \\
\hline Kansas & & & $30-\mathrm{mrt}$ & \\
\hline Kentucy & & & 26-mrt & \\
\hline Louisiana & & & 23-mrt & \\
\hline Maryland & & & $30-\mathrm{mrt}$ & \\
\hline Massachusetts & & & 24-mrt & \\
\hline Michigan & & & 24-mrt & \\
\hline Minnesota & & & 27-mrt & \\
\hline Missouri & & & & $63 \%$ \\
\hline & & Kansas City & 24-mrt & \\
\hline & & St. Joseph & 24-mrt & \\
\hline & & St. Louis & 24-mrt & \\
\hline & Boone & & $25-\mathrm{mrt}$ & \\
\hline & Cass & & 24-mrt & \\
\hline & Clay & & 24-mrt & \\
\hline & Cole & & $26-\mathrm{mrt}$ & \\
\hline & Greene & & 26-mrt & \\
\hline & Jackson & & 24-mrt & \\
\hline & Jefferson & & 24-mrt & \\
\hline & Platte & & 24-mrt & \\
\hline
\end{tabular}




\begin{tabular}{|c|c|c|c|c|}
\hline STATE & COUNTY & MUNICIPALITY & DATE & $\begin{array}{l}\% \text { OF } \\
\text { STATE }\end{array}$ \\
\hline & Randolph & & 25-mrt & \\
\hline & Ray & & 25-mrt & \\
\hline & St. Louis County & & 23-mrt & \\
\hline Montana & & & 28-mrt & \\
\hline New Hampshire & & & 27-mrt & \\
\hline New Jersey & & & 21-mrt & \\
\hline New Mexico & & & 24-mrt & \\
\hline New York & & & 22-mrt & \\
\hline North Carolina & & & $30-\mathrm{mrt}$ & \\
\hline Ohio & & & 23-mrt & \\
\hline Oregon & & & 23-mrt & \\
\hline \multirow[t]{22}{*}{ Pennsylvania } & & & & $71 \%$ \\
\hline & Allegheny & & 23-mrt & \\
\hline & Beaver & & 28-mrt & \\
\hline & Berks & & 27-mrt & \\
\hline & Bucks & & 23-mrt & \\
\hline & Butler & & 27-mrt & \\
\hline & Centre & & 28-mrt & \\
\hline & Chester & & 23-mrt & \\
\hline & Delaware & & 23-mrt & \\
\hline & Eerie & & 24-mrt & \\
\hline & Lackawanna & & 27-mrt & \\
\hline & Lehigh & & 25-mrt & \\
\hline & Luzerne & & 27-mrt & \\
\hline & Monroe & & 23-mrt & \\
\hline & Montgomery & & 23-mrt & \\
\hline & Northampton & & 25-mrt & \\
\hline & Philadelphia & & 23-mrt & \\
\hline & Pike & & 27-mrt & \\
\hline & Washington & & 28-mrt & \\
\hline & Wayne & & 27-mrt & \\
\hline & Westmoreland & & 27-mrt & \\
\hline & York & & 27-mrt & \\
\hline Rhode Island & & & 28-mrt & \\
\hline \multirow[t]{9}{*}{ Texas } & & & & $74 \%$ \\
\hline & & Amarillo & 30-mrt & \\
\hline & Bell & & 23-mrt & \\
\hline & Bexar & & 24-mrt & \\
\hline & Brazoria & & 26-mrt & \\
\hline & Cameron & & $25-\mathrm{mrt}$ & \\
\hline & Chambers & & 24-mrt & \\
\hline & Collin & & 24-mrt & \\
\hline & Dallas & & 23-mrt & \\
\hline
\end{tabular}




\begin{tabular}{|c|c|c|c|c|}
\hline STATE & COUNTY & MUNICIPALITY & DATE & $\begin{array}{l}\% \text { OF } \\
\text { STATE }\end{array}$ \\
\hline & Denton & & $25-\mathrm{mrt}$ & \\
\hline & El Paso & & 24-mrt & \\
\hline & Ellis & & $25-\mathrm{mrt}$ & \\
\hline & Fort Bend & & $25-\mathrm{mrt}$ & \\
\hline & Galveston & & 24-mrt & \\
\hline & Gregg & & 26-mrt & \\
\hline & Harris & & 24-mrt & \\
\hline & Hays & & 26-mrt & \\
\hline & Hidalgo & & 26-mrt & \\
\hline & Hunt & & 24-mrt & \\
\hline & Kaufman & & 25-mrt & \\
\hline & Liberty & & 24-mrt & \\
\hline & McLennan & & 23-mrt & \\
\hline & Nacogdoches & & 30-mrt & \\
\hline & Nueces & & 26-mrt & \\
\hline & Polk & & 27-mrt & \\
\hline & Robertson & & $25-\mathrm{mrt}$ & \\
\hline & Rockwall & & 24-mrt & \\
\hline & San Jacinto & & 25-mrt & \\
\hline & Scurry & & 27-mrt & \\
\hline & Smith & & 27-mrt & \\
\hline & Starr & & $25-\mathrm{mrt}$ & \\
\hline & Tarrant & & 24-mrt & \\
\hline & Travis & & 24-mrt & \\
\hline & Willacy & & 26-mrt & \\
\hline & Williamson & & 24-mrt & \\
\hline Vermont & & & 25-mrt & \\
\hline Washington & & & 23-mrt & \\
\hline West - Virginia & & & 24-mrt & \\
\hline Wisconsin & & & 25-mrt & \\
\hline
\end{tabular}




\section{References}

Adler, Nancy E, Elissa S Epel, Grace Castellazzo, and Jeannette R Ickovics. 2000. "Relationship of subjective and objective social status with psychological and physiological functioning: Preliminary data in healthy white women." Health Psychology 19 (6):586.

Agnew, Robert. 1992. "Foundation for a general strain theory of crime and delinquency." Criminology 30 (1):47-88.

Agnew, Robert. 2006. "Pressured into crime: An overview of general strain theory."

Agnew, Robert, Timothy Brezina, John Paul Wright, and Francis T Cullen. 2002. "Strain, personality traits, and delinquency: Extending general strain theory." Criminology 40 (1):43-72.

Agnew, Robert, and Helene Raskin White. 1992. "An empirical test of general strain theory." Criminology 30 (4):475-500.

Apel, Robert. 2013. "Sanctions, perceptions, and crime: Implications for criminal deterrence." Journal of quantitative criminology 29 (1):67-101.

Bachmann, Laura H, Joan Stephens, Charity M Richey, and EDWARD W HOOK III. 1999. "Measured versus self-reported compliance with doxycycline therapy for chlamydiaassociated syndromes: high therapeutic success rates despite poor compliance." Sexually transmitted diseases 26 (5):272-278.

Baker, Thomas, and Jacinta M Gau. 2018. "Female offenders' perceptions of police procedural justice and their obligation to obey the law." Crime \& Delinquency 64 (6):758-781.

Baron, Stephen W. 2004. "General strain, street youth and crime: A test of Agnew's revised theory." Criminology 42 (2):457-484.

Baum, Matthew A, and Tim Groeling. 2008. "New media and the polarization of American political discourse." Political Communication 25 (4):345-365.

Becker, Gary S. 1968. "Crime and Punishment, An Economic Approach." Journal of Political Economy 76:169-217.

Botchkovar, Ekaterina V, Charles R Tittle, and Olena Antonaccio. 2009. "General strain theory: Additional evidence using cross-cultural data." Criminology 47 (1):131-176.

Brooks, Samantha K, Rebecca K Webster, Louise E Smith, Lisa Woodland, Simon Wessely, Neil Greenberg, and Gideon James Rubin. 2020. "The psychological impact of quarantine and how to reduce it: rapid review of the evidence." The Lancet.

Brown, Don W. 1978. "Arrest rates and crime rates: when does a tipping effect occur?" Social Forces 57 (2):671-682.

Chamlin, Mitchell B. 1991. "A longitudinal analysis of the arrest-crime relationship: A further examination of the tipping effect." Justice Quarterly 8 (2):187-199.

Cialdini, Robert B, Linda J Demaine, Brad J Sagarin, Daniel W Barrett, Kelton Rhoads, and Patricia L Winter. 2006. "Managing social norms for persuasive impact." Social Influence 1 (1):3-15.

Cialdini, Robert B., and Noah J. Goldstein. 2004. "Social influence: compliance and conformity." Annual Review of Psychology 55:591-621. doi: 10.1146/annurev.psych.55.090902.142015.

Clarke, Ronald V. 2005. "Seven misconceptions of situational crime prevention." In Handbook of crime prevention and community safety, edited by Nick Tilley, 39-70. New York, NY: Routledge.

Clarke, Ronald VG. 1980. "" Situational" Crime Prevention: Theory and Practice." The British Journal of Criminology 20 (2):136-147. 
Cohen, Lawrence E, and Marcus Felson. 1979. "Social change and crime rate trends: A routine activity approach." American sociological review 44 (4):588-608.

Darley, John M, Kevin M Carlsmith, and Paul H Robinson. 2001. "The ex ante function of the criminal law." Law and Society Review 35 (1):165-190.

Decker, Scott H., Richard Wright, and Robert Logie. 1993. "Perceptual Deterrence among active residential burglars: a research note." Criminology 31 (135-147).

Dieltjens, Marijke, Marc J Braem, Anneclaire VMT Vroegop, Kristien Wouters, Johan A Verbraecken, Wilfried A De Backer, Paul H Van de Heyning, and Olivier M Vanderveken. 2013. "Objectively measured vs self-reported compliance during oral appliance therapy for sleep-disordered breathing." Chest 144 (5):1495-1502.

Donovan, Jenny L, and David R Blake. 1992. "Patient non-compliance: deviance or reasoned decision-making?" Social science \& medicine 34 (5):507-513.

Estévez, Estefanía, and Nicholas P Emler. 2010. "A structural modelling approach to predict adolescent offending behaviour from family, school and community factors." European Journal on Criminal Policy and Research 16 (4):207-220.

Everett, JAC, C Colombatto, V Chituc, WJ Brady, and MJ Crockett. 2020. "[Pre-print]. The effectiveness of moral messages on public health behavioral intentions during the COVID-19 pandemic." doi: 10.31234/osf.io/9yqs8.

Feldman, Yuval. 2018. The law of good people: Challenging states' ability to regulate human behavior: Cambridge University Press.

Feldman, Yuval, and Doron Teichman. 2009. "Are all legal probabilities created equal." NYUL Rev. 84:980.

Fine, Adam D, Zachary Rowan, and Cortney Simmons. 2019. "Do politics Trump race in determining America's youths' perceptions of law enforcement?" Journal of Criminal Justice 61:48-57.

Fine, Adam, April Thomas, Benjamin van Rooij, and Elizabeth Cauffman. 2020. "AgeGraded Differences and Parental Influences on Adolescents' Obligation to Obey the Law." Journal of Developmental and Life-Course Criminology:1-18.

Fine, Adam, Benjamin Van Rooij, Yuval Feldman, Shaul Shalvi, Margerita Leib, Eline Scheper, and Elizabeth Cauffman. 2016. "Rule Orientation and Behavior: Development and Validation of a Scale Measuring Individual Acceptance of Rule Violation." Psychology, Public Policy, and Law 22 (3):314-329.

Fletcher, Richard, and Rasmus Kleis Nielsen. 2017. "Are news audiences increasingly fragmented? A cross-national comparative analysis of cross-platform news audience fragmentation and duplication." Journal of Communication 67 (4):476-498.

Friedman, Lawrence M. 2016. Impact: Harvard University Press.

Garber, Mathew C, David P Nau, Steven R Erickson, James E Aikens, and Joseph B Lawrence. 2004. "The concordance of self-report with other measures of medication adherence: a summary of the literature." Medical care:649-652.

Gau, Jacinta M. 2014. "Procedural justice and police legitimacy: A test of measurement and structure." American Journal of Criminal Justice 39 (2):187-205.

Glanz, J, B Carey, J Holder, D Watkins, J Valentino-DeVries, R Rojas, and L Leatherby. 2020, April 2. "Where Americans Didn't Stay Home Even as the Virus Spread." The New York Times. https://www.nytimes.com/interactive/2020/04/02/us/coronavirussocial-distancing.html.

Goldstein, Noah J., Robert B. Cialdini, and Vladas Griskevicius. 2008. "A room with a viewpoint: using social norms to motivate environmental conservation in hotels." Journal of Consumer Research 35:472-482.

Gottfredson, Michael R, and Travis Hirschi. 1990. A general theory of crime: Stanford University Press. 
Grasmick, Harold G, and George J Bryjak. 1980. "The deterrent effect of perceived severity of punishment." Social Forces 59 (2):471-491.

Harper, CA, LP Satchell, D Fido, and RD Latzman. 2020. "[Pre-print]. Functional fear predicts public health compliance in the COVID-19 pandemic." doi: 10.31234/osf.io/jkfu3.

Hasson, Yossi, Maya Tamir, Kea S Brahms, J Christopher Cohrs, and Eran Halperin. 2018. "Are liberals and conservatives equally motivated to feel empathy toward others?" Personality and Social Psychology Bulletin 44 (10):1449-1459.

I\&O Research, and Universiteit Twente. 2020. Rapport: Het Corona- en het eenzaamheidsvirus. Amsterdam: I\&O Research.

Jung, Sung-mok, Andrei R Akhmetzhanov, Katsuma Hayashi, Natalie M Linton, Yichi Yang, Baoyin Yuan, Tetsuro Kobayashi, Ryo Kinoshita, and Hiroshi Nishiura. 2020. "Realtime estimation of the risk of death from novel coronavirus (COVID-19) infection: Inference using exported cases." Journal of clinical medicine 9 (2):523.

Kim, Pauline T. 1999. "Norms, Learning and Law: Exploring the Influences of Workers' Legal Knowledge." University of Illinois Legal Review 1999 (2):447-516.

Kushner Gadarian, S, S Wallace Goodman, and TB Pepinsky. 2020. "[Pre-print]. Partisanship, health behavior, and policy attitudes in the early stages of the COVID19 pandemic." doi: 10.2139/ssrn.3562796

Lunn, PD, S Timmons, CA Belton, M Barjaková, H Julienne, and C Lavin. 2020. "[Preprint]. Motivating social distancing during the Covid-19 pandemic: An online experiment." doi: 10.31234/osf.io/x4agb.

Maekelae, MJ, K Klevjer, N Reggev, RM Tamayo, N Dutra, G Briganti, RA Silva-Sobrinho, and G Pfuhl. 2020. "[Pre-print]. Perceived efficacy of actions and feelings of distress during the early phase of the COVID-19 outbreak in Norway, Germany, Israel, Colombia and Brazil." doi: 10.31234/osf.io/ce4n3.

McCright, Aaron M, Katherine Dentzman, Meghan Charters, and Thomas Dietz. 2013. "The influence of political ideology on trust in science." Environmental Research Letters 8 (4):044029.

Miller, Richard L. 1976. "Mere Exposure, Psychological Reactance and Attitude Change." The Public Opinion Quarterly 40 (2):229-233.

Nagin, Daniel S. 2013. "Deterrence in the Twenty-first Century." Crime and Justice 42 (1):199-263.

Nagin, Daniel S, Francis T Cullen, and Cheryl Lero Jonson. 2009. "Imprisonment and reoffending." Crime and justice 38 (1):115-200.

Nagin, Daniel S, and John V Pepper, eds. 2012. Deterrence and the death penalty. Washington DC: National Academies Press.

Nagin, Daniel S, and Cody W Telep. 2017. "Procedural justice and legal compliance." Annual Review of Law and Social Science 13:5-28.

Oosterhoff, B, and CA Palmer. 2020. "[Pre-print]. Psychological correlates of news monitoring, social distancing, disinfecting, and hoarding behaviors among US adolescents during the COVID-19 pandemic." doi: 10.31234/osf.io/rpcy4.

Osgood, D Wayne, Janet K Wilson, Patrick M O'malley, Jerald G Bachman, and Lloyd D Johnston. 1996. "Routine activities and individual deviant behavior." American Sociological Review:635-655.

Paternoster, Raymond, and Sally Simpson. 1993. "A rational choice theory of corporate crime." Routine activity and rational choice 5:37.

Piquero, Nicole Leeper, and Miriam D Sealock. 2004. "Gender and general strain theory: A preliminary test of Broidy and Agnew's gender/GST hypotheses." Justice quarterly $21(1): 125-158$. 
Polinsky, A Mitchell, and Steven Shavell. 2000. "Public Enforcement of Law." In Encyclopedia of Law and Economics, Volume V. The Economics of Crime and Litigation, edited by Boudewijn Bouckaert and Gerrit De Geest, 307-344. Cheltenham: Edward Elgar.

Posch, Krisztian, Jonathan Jackson, Ben Bradford, and Sarah Macqueen. 2020. "' Truly Free Consent"? Clarifying the Nature of Police Legitimacy using Causal Mediation Analysis." Journal of Experimental Criminology.

Pratt, Travis C, and Francis T Cullen. 2000. "The empirical status of Gottfredson and Hirschi's general theory of crime: A meta-analysis." Criminology 38 (3):931-964.

Pratt, Travis C, and Francis T Cullen. 2005. "Assessing macro-level predictors and theories of crime: A meta-analysis." Crime and justice 32:373-450.

Pratt, Travis C, and Kristin Llouyd. 2021 (forthcoming). "Self-control and Offending." In The Cambridge Handbook on Compliance, edited by Benjamin Van Rooij and D Daniel Sokol. Cambridge UK: Cambridge University Press.

Prior, Markus. 2013. "Media and political polarization." Annual Review of Political Science 16:101-127.

Quick, Brian L., and Michael T. Stephenson. 2007. "Further Evidence That Psychological Reactance Can Be Modeled as a Combination of Anger and Negative Cognitions." Communication Research 34 (3):255-276. doi: 10.1177/0093650207300427.

Rauscher, Helmuth, Dieter Formanek, Wolfgang Popp, and Hartmut Zwick. 1993. "Selfreported vs measured compliance with nasal CPAP for obstructive sleep apnea." Chest 103 (6):1675-1680.

Reich, John W, and Jerie L Robertson. 1979. "Reactance and Norm Appeal in Anti-Littering Messages." Journal of Applied Social Psychology 9 (1):91-101.

Reisig, Michael D, Jason Bratton, and Marc G Gertz. 2007. "The construct validity and refinement of process-based policing measures." Criminal justice and behavior 34 (8):1005-1028.

Ridgers, Nicola D, Anna Timperio, David Crawford, and Jo Salmon. 2012. "Validity of a brief self-report instrument for assessing compliance with physical activity guidelines amongst adolescents." Journal of Science and Medicine in Sport 15 (2):136-141.

Schultz, P. Wesley, Jessica M. Nolan, Robert B. Cialdini, Noah J. Goldstein, and Vladas Griskevicius. 2007. "The constructive, destructive, and reconstructive power of social norms." Psychological Science 18 (5):429-434.

Shavell, Steven. 1991. "Specific versus General Enforcement of Law." Journal of Political Economy 99:1099-1108.

Simpson, Sally, Melissa Rorie, Mariel Elise Alper, Natalie Schell-Busey, William Laufer, and N Craig Smith. 2014. "Corporate Crime Deterrence: A Systematic Review." Campbell Systematic Reviews 10 (4):5-88.

Soper, George A. 1919. "The Lessons of the Pandemic." Science 49 (1274):501-506. doi: 10.1126/science.49.1274.501.

Spano, Richard, and Joshua D Freilich. 2009. "An assessment of the empirical validity and conceptualization of individual level multivariate studies of lifestyle/routine activities theory published from 1995 to 2005." Journal of Criminal Justice 37 (3):305-314.

Spohr, Dominic. 2017. "Fake news and ideological polarization: Filter bubbles and selective exposure on social media." Business Information Review 34 (3):150-160.

Tankebe, Justice, Michael D Reisig, and Xia Wang. 2016. "A multidimensional model of police legitimacy: A cross-cultural assessment." Law and Human Behavior 40 (1):11.

Tyler, Tom. 2017. "Procedural justice and policing: A rush to judgment?" Annual Review of Law and Social Science 13:29-53. 
Tyler, Tom R. 1997. "Procedural Fairness and Compliance with the Law." Swiss Journal of Economics and Statistics 133 (2):p. 219-240.

Tyler, Tom R. 2006. Why People Obey the Law. Princeton: Princeton University Press.

Van Rooij, Benjamin. 2021 (Forthcoming). "Do people know the law? Empirical evidence about legal knowledge and its implications for compliance." In Cambridge Handbook of Compliance, edited by Benjamin van Rooij and D Daniel Sokol. Cambridge, UK: Cambridge University Press.

Van Rooij, Benjamin, and D Daniel Sokol. 2021 (Forthcoming). "Compliance as the interaction between rules and behavior (Introduction to Cambridge Handbook of Compliance)." In Cambridge Handbook of Compliance, edited by D Daniel Sokol and Benjamin Van Rooij. Cambridge, UK: Cambridge University Press.

Vazsonyi, Alexander T, Jakub Mikuška, and Erin L Kelley. 2017. "It's time: A meta-analysis on the self-control-deviance link." Journal of Criminal Justice 48:48-63.

Walker, Patrick, Charles Whittaker, Oliver Watson, Marc Baguelin, Kylie Ainslie, Sangeeta Bhatia, Samir Bhatt, Adhiratha Boonyasiri, Olivia Boyd, Lorenzo Cattarino, Zulma Cucunubá, Gina Cuomo-Dannenburg, Amy Dighe, Christl Donnelly, Ilaria Dorigatti, Sabine van Elsland, Rich FitzJohn, Seth Flaxman, Han Fu, Katy Gaythorpe, Lily Geidelberg, Nicholas Grassly, Will Green, Arran Hamlet, Katharina Hauck, David Haw, Sarah Hayes, Wes Hinsley, Natsuko Imai, David Jorgensen, Edward Knock, Daniel Laydon, Swapnil Mishra, Gemma Nedjati-Gilani, Lucy Okell, Steven Riley, Hayley Thompson, Juliette Unwin, Robert Verity, Michaela Vollmer, Caroline Walters, Hao Wei Wang, Yuanrong Wang, Peter Winskill, Xiaoyue Xi, Neil Ferguson, and Azra Ghan. 2020. "The Global Impact of COVID-19 and Strategies for Mitigation and Suppression." Imperial College Covid-19 Reports (12).

Walters, Glenn D, and P Colin Bolger. 2019. "Procedural justice perceptions, legitimacy beliefs, and compliance with the law: A meta-analysis." Journal of experimental Criminology 15 (3):341-372.

Weinberger, Daniel A, and Gary E Schwartz. 1990. "Distress and restraint as superordinate dimensions of self-reported adjustment: A typological perspective." Journal of personality 58 (2):381-417.

Weiss, Paul, and David R Murdoch. 2020. "Clinical course and mortality risk of severe COVID-19." The Lancet.

Wojcik, Sean P, Arpine Hovasapian, Jesse Graham, Matt Motyl, and Peter H Ditto. 2015. "Conservatives report, but liberals display, greater happiness." Science 347 (6227):1243-1246.

Wolfe, Scott E, Justin Nix, Robert Kaminski, and Jeff Rojek. 2016. "Is the effect of procedural justice on police legitimacy invariant? Testing the generality of procedural justice and competing antecedents of legitimacy." Journal of quantitative criminology 32 (2):253-282.

Zettler, I, C Schild, : Lilleholt, and R Böhm. 2020. "[Pre-print]. Individual differences in accepting personal restrictions to fight the COVID-19 pandemic: Results from a Danish adult sample." doi: 10.31234/osf.io/pkm2a.

Zhou, Fei, Ting Yu, Ronghui Du, Guohui Fan, Ying Liu, Zhibo Liu, Jie Xiang, Yeming Wang, Bin Song, and Xiaoying Gu. 2020. "Clinical course and risk factors for mortality of adult inpatients with COVID-19 in Wuhan, China: a retrospective cohort study." The Lancet.

\footnotetext{
${ }^{1}$ The authors wish to thank Yuval Feldman and Shuyu Huang for their excellent input on this research.

${ }^{2}$ https://www.nytimes.com/2020/03/31/us/politics/coronavirus-death-toll-united-states.html
} 
${ }^{3}$ https://www.nytimes.com/interactive/2020/us/coronavirus-stay-at-home order.html?referringSource=articleShare

${ }^{4}$ Id.

${ }^{5}$ Id.

${ }^{6} \mathrm{Id}$.

${ }^{7}$ Id.

${ }^{8} \mathrm{https://www.nytimes.com/2020/03/16/smarter-living/coronavirus-social-distancing.html}$

9 https://www.nytimes.com/interactive/2020/03/23/opinion/coronavirus-economy-recession.html

${ }^{10} \mathrm{https}: / / \mathrm{www} . v 0 x . c o m / 2020 / 4 / 14 / 21220474 /$ trump-coronavirus-video-white-house-briefing

${ }^{11} \mathrm{https} / / \mathrm{www}$.latimes.com/california/story/2020-03-16/lapd-shifting-more-cops-to-street-patrol-to-help-withthe-coronavirus

${ }^{12} \mathrm{https} / / /$ patch.com/washington/seattle/inslee-outlines-potential-enforcement-stay-home-orders

${ }^{13} \mathrm{https}$ ://nypost.com/2020/03/25/de-blasio-removing-some-city-basketball-hoops-to-stop-games-duringcoronavirus/

${ }^{14}$ https://eu.usatoday.com/story/news/health/2020/03/19/coronavirus-updates-us-china-nyc-cases-testingunemployment-cdc/2866751001/ for a similar appeal from Michigan Governor Gretchen Whitmer see https://www.fox2detroit.com/news/gov-gretchen-whitmer-urges-michigan-residents-to-stay-the-course-onsocial-distancing-as-protesters-loom

${ }^{15}$ See for instance https://www.klcc.org/post/governors-order-could-help-flatten-curve-oregon and https://www.fox2detroit.com/news/gov-gretchen-whitmer-urges-michigan-residents-to-stay-the-course-onsocial-distancing-as-protesters-loom and https://www.washingtonexaminer.com/politics/louisiana-takingdrastic-measures-as-gov-edwards-asks-everyone-to-help-flatten-the-curve

${ }^{16}$ Two participants were excluded on both accounts, resulting in some overlap in these two exclusion categories.

${ }^{17}$ Additionally, we measured willingness to report, and participants indicated for several COVID-19 measures whether they applied to them at the moment of participation. These measures will be discussed in separate papers and are not included in the present analyses.

${ }^{18} \mathrm{https} / / /$ www.gstatic.com/covid19/mobility/2020-04-11_US_Mobility_Report_en.pdf

${ }^{19} \mathrm{https} / / /$ www.gstatic.com/covid19/mobility/2020-04-11_US_Mobility_Report_en.pdf

${ }^{20} \mathrm{https} / / / \mathrm{www}$. washingtonpost.com/business/2020/04/16/unemployment-claims-coronavirus/

${ }^{21} \mathrm{https}$ ://www.nytimes.com/interactive/2020/us/coronavirus-stay-at-home-

order.html?referringSource=articleShare 